\title{
Taxonomic notes on the Rhynchosia densiflora group (Phaseoleae, Fabaceae) in South Africa and its segregation from Rhynchosia section Arcyphyllum
}

\begin{tabular}{|c|c|}
\hline \multicolumn{2}{|c|}{$\begin{array}{l}\text { Authors: } \\
\text { Thulisile P. Jaca }{ }^{1,2} \text { (1) } \\
\text { Annah N. Moteetee }\end{array}$} \\
\hline \multicolumn{2}{|c|}{$\begin{array}{l}\text { Affiliations: } \\
{ }^{1} \text { South African National } \\
\text { Biodiversity Institute (SA } \\
\text { National Herbarium, } \\
\text { South Africa }\end{array}$} \\
\hline \multicolumn{2}{|c|}{$\begin{array}{l}{ }^{2} \text { Department of Botany and } \\
\text { Plant Biotechnology, } \\
\text { University of Johannesburg, } \\
\text { South Africa }\end{array}$} \\
\hline \multicolumn{2}{|c|}{$\begin{array}{l}\text { Corresponding author: } \\
\text { Thulisile Jaca, } \\
\text { t.jaca@sanbi.org.za }\end{array}$} \\
\hline \multicolumn{2}{|c|}{$\begin{array}{l}\text { Dates: } \\
\text { Received: } 29 \text { Sept. } 2017 \\
\text { Accepted: } 08 \text { May } 2018 \\
\text { Published: } 19 \text { June } 2018\end{array}$} \\
\hline \multicolumn{2}{|c|}{$\begin{array}{l}\text { How to cite this article: } \\
\text { Jaca, T.P. \& Moteetee, A.N., } \\
\text { 2018, 'Taxonomic notes on } \\
\text { the Rhynchosia densiflora } \\
\text { group (Phaseoleae, } \\
\text { Fabaceae) in South Africa } \\
\text { and its segregation from } \\
\text { Rhynchosia section } \\
\text { Arcyphyllum', Bothalia 48(1), } \\
\text { a2305. https://doi.org/ } \\
\text { 10.4102/abc.v48i1.2305 }\end{array}$} \\
\hline \multicolumn{2}{|c|}{$\begin{array}{l}\text { Copyright: } \\
\text { ( } 2018 \text {. The Authors. } \\
\text { Licensee: AOSIS. This work } \\
\text { is licensed under the } \\
\text { Creative Commons } \\
\text { Attribution License. }\end{array}$} \\
\hline \multicolumn{2}{|l|}{ Read online } \\
\hline 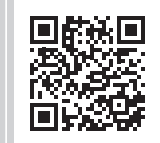 & $\begin{array}{l}\text { Scan this QR } \\
\text { code with your } \\
\text { smart phone or } \\
\text { mobile device } \\
\text { to read online. }\end{array}$ \\
\hline
\end{tabular}

Background: Rhynchosia section Arcyphyllum is one of the five sections of Rhynchosia as currently circumscribed. Previous studies in South Africa placed two species of Rhynchosia in this section. Some authors treated the species as a group rather than a section, to avoid phytogeographical confusion because the section is based on the North American generic name Arcyphyllum.

Objectives: To formally remove the South African taxa from section Arcyphyllum and to provide diagnostic features for these taxa, a key to the subspecies, distribution maps and an illustration of their morphological features.

Methods: Observations were made on herbarium specimens housed at NH, NU and PRE. Several field trips were undertaken in search of Rhynchosia connata. Morphological and anatomical features were studied and measurements of characters recorded.

Results: In South Africa, the section was until now represented by two species, Rhynchosia densiflora (subsp. chrysadenia) and $R$. connata. These were separated primarily on stem indumentum, stipule shape, petiole length, leaflet shape and apices. However, this study revealed that there are no clear discontinuities between the two taxa apart from the lobes of the uppermost calyx lip, which are connate more than halfway in $R$. connata and up to halfway in $R$. densiflora subsp. chrysadenia. Therefore, $R$. connata is here relegated to varietal level as $R$. densiflora subsp. chrysadenia var. connata (Baker f.) Jaca \& Moteetee.

Conclusions: Two varieties of Rhynchosia densiflora subsp. chrysadenia occur in South Africa and are treated as part of the R. densiflora group instead of section Arcyphyllum.

\section{Introduction}

Rhynchosia sect. Arcyphyllum Torr. \& Gray is based on the generic name Arcyphyllum Ell., erected by Elliott (1818) for three species previously placed in Glycine L. by Pursh (1814), viz. Arcyphyllum simplicifolium (Walter) Ell. [=Rhynchosia reniformis (Pursh) DC.], Arcyphyllum difforme Ell. [=Rhynchosia difformis (Ell.) DC.] and Arcyphyllum erectum (Walter) Ell. [=Rhynchosia tomentosa (L.) Hook. \& Arn]. However, Elliott (1824) transferred these species back to Glycine without any reference to the name Arcyphyllum. Torrey and Gray (1838), in their treatment of Rhynchosia in North America, recognised the two sections R. sect. (Eu)Rhynchosia, with one species (Rhynchosia caribaea DC.), and Rhynchosia sect. Arcyphyllum (Ell.) Torr. \& Gray, with three species [Rhynchosia menispermoidea DC., Rhynchosia tomentosa Torr. \& Gray (with five infraspecific variants) and Rhynchosia latifolia Nutt. ex Torr. \& Gray]. The distinction between these species was based on growth habit, stem pubescence, stipule shape, leaflet shape and indumentum, flower number, shape of calyx lobes and the degree of connation of the upper lip, as well as fruit shape and pubescence.

Endlicher (1840) presented an account of the genus Rhynchosia for America and Australia, listing six sections: sect. Copisma E.Mey., sect. Arcyphyllum Ell. Torr. \& Gray, sect. Phyllomatia Wight \& Arn., sect. Ptychocentrum Wight \& Arn., sect. Pitcheria Nutt. and sect. Rhynchosia, but he did not enumerate the species within these sections.

Bentham (1859) discussed ten South American species of Rhynchosia, of which four were newly described, treated in sect. Copisma comprising four species, viz. Rhynchosia phaseoloides (Sw.) DC., 
Rhynchosia minima DC., Rhynchosia senna Hook. and Rhynchosia lobata Desv., and sect. Arcyphyllum consisting of six species, viz. Rhynchosia platyphylla Benth., Rhynchosia claussenii Benth., Rhynchosia corylifolia Mart., Rhynchosia leucophylla Benth., Rhynchosia lineata Benth. and Rhynchosia reticulata DC. Bentham (1865) recognised 72 species of Rhynchosia worldwide and placed them in 11 sections [sect. Arcyphyllum (Ell.) Torrey \& Gray (12 spp.), sect. Chrysoscias E.Mey. (4 spp.), sect. Copisma (30 spp.), sect. Cyanospermum Wight \& Arn. (2 spp.), sect. Nomismia Wight \& Arn. (3 spp.), sect. Orthodanum E.Mey. (4 spp.), sect. Phaseoloides Mart. (4 spp.), sect. Phyllomatia Wight \& Arn. (2 spp.), sect. Polytropia Presl. (2 spp.), sect. Pseudocajan Jacq. (4 spp.) and sect. Ptychocentrum Wight \& Arn. (5 spp.)]. These 11 sections were again presented by Taubert (1894), but he estimated that there were now more than 100 species. In his treatment of the Flora of Tropical Africa, Baker (1871) placed two African species (Rhynchosia debilis Hook. and R. densiflora DC.) in section Arcyphyllum based on their twining habit and the densely clustered flowers. The former species was reduced by Verdcourt (1971) to a subspecies of $R$. densiflora. In his revision of the genus in South Africa, Baker (1923) retained $R$. densiflora in this section and added a new species $R$. connata Baker f. The distinction between these two species was based on the shape of the terminal leaflet (broadly ovate and acuminate in $R$. densiflora and rhombic-ovate and obtuse in $R$. connata). A summary of the history of sectional classification of Rhynchosia section Arcyphyllum is presented in Table 1. Baker (1923) further merged sect. Copisma and sect. Orthodanum into sect. Eurhynchosia, now treated as sect. Rhynchosia.

In two treatments of African Rhynchosia species (Gillett, Polhill \& Verdcourt 1971; Verdcourt 2001), R. densiflora was not placed in sect. Arcyphyllum, but treated as a separate group (the $R$. densiflora group) to avoid phytogeographical confusion because the centre of diversity for sect. Arcyphyllum species is in North America. Based on Torrey and Gray (1838), sections Rhynchosia and Arcyphyllum differ essentially in features of the calyx. In sect. Rhynchosia, the stems are always twining and the calyx is marcescent with subulate segments, of which the lowest one is the longest, while in sect. Arcyphyllum the stems are sometimes erect, or commonly twining or trailing, and the calyx is persistent and foliaceous, with linear or oblong-lanceolate, acuminate segments which are nearly equal. Grear (1978), supported by Fortunato (2000), has concluded that in sect. Arcyphyllum the stems are mostly erect or prostrate and rarely twining. In the South African taxa formerly included in sect. Arcyphyllum, the calyx lobes are foliaceous, linear or linear-lanceolate, and equal or longer than the corolla, but the lowermost lobe is the longest and the stems are climbing as in sect. Rhynchosia. However, the $R$. densiflora group differs from sect. Rhynchosia in the densely clustered flowers. According to Grear (1978), taxa with trifoliolate leaves in sect. Arcyphyllum tend to have unifoliolate older leaves, but no specimens of the $R$. densiflora group have this kind of leaf structure (we have also examined some specimens of the East African taxa, i.e. R. densiflora subsp. debilis and subsp. stuhlmannii). For these reasons, we follow Gillett et al. (1971) and Verdcourt (2001) in segregating the $R$. densiflora group from sect. Arcyphyllum, but refrain from recognising sectional status because preliminary molecular data indicate that Baker's (1923) sectional classification of the South African species of Rhynchosia is not supported (Manyelo 2014). Furthermore, molecular and detailed morphological analyses are currently underway.

In recent checklists and floristic treatments (Germishuizen et al. 2006; Gillett et al. 1971; Verdcourt 1971), R. densiflora has been considered to comprise four subspecies, that is, $R$. densiflora subsp. densiflora, $R$. densiflora subsp. chrysadenia (Taub.) Verdc., $R$. densiflora subsp. stuhlmannii (Harms) Verdc. and $R$. densiflora subsp. debilis (G.Don) Verdc., with only $R$. densiflora subsp. chrysandenia occurring in

TABLE 1: Summary of the history of sectional classification of Rhynchosia section Arcyphyllum (current names are indicated in brackets).

\begin{tabular}{|c|c|c|c|c|}
\hline Author(s) & Generic name & Sections & $\begin{array}{l}\text { Number of species in } \\
\text { Arcyphyllum }\end{array}$ & Species in Arcyphyllum \\
\hline Elliott (1818) & Arcyphyllum Ell. & - & 3 spp. & $\begin{array}{l}\text { A. simplicifolium (Walter) Ell. (=Rhynchosia } \\
\text { reniformis (Pursh) DC.), A. difforme Ell. } \\
\text { (=Rhynchosia difformis (EII.) DC.), A. erectum } \\
\text { (Walter) Elliott (=Rhynchosia tomentosa (L.) } \\
\text { Hook. \& Arn) }\end{array}$ \\
\hline Torrey and Gray (1838) & Rhynchosia Lour. & EuRhynchosia Arn., Arcyphyllum Ell. & 3 spp. & $\begin{array}{l}\text { R. menispermoidea DC., R. tomentosa Torr. \& } \\
\text { Gray (with five infraspecific variants), R. latifolia } \\
\text { Nutt. ex Torr. \& Gray. }\end{array}$ \\
\hline Endlicher (1840) & Rhynchosia Lour. & $\begin{array}{l}\text { Arcyphyllum Ell., Copisma E.Mey., Eurhynchosia } \\
\text { Endl., Phyllomatia Wight \& Arn., Pitcheria Nutt., } \\
\text { Ptychocentrum Wight \& Arn. }\end{array}$ & \multicolumn{2}{|c|}{ No species enumerated in these sections } \\
\hline Bentham (1859) & Rhynchosia Lour. & Copisma E.Mey., Arcyphyllum Ell. & $6 \mathrm{spp}$. & $\begin{array}{l}\text { R. platyphylla Benth., } R \text {. claussenii Benth., } \\
\text { R. corylifolia Mart., R. leucophylla Benth., } \\
\text { R. lineata Benth., R. reticulata DC. }\end{array}$ \\
\hline Bentham (1865) & Rhynchosia Lour. & $\begin{array}{l}\text { Arcyphyllum Ell., Copisma E.Mey., Chrysoscias } \\
\text { E.Mey., Cyanospermum (Wight \& Arn.) Benth., } \\
\text { Nomismia Wight \& Arn., Orthodanum E.Mey., } \\
\text { Phyllomatia Benth., Phaseoloides DC., Polytropia } \\
\text { Presl., Pseudocajan Jacq., Ptychocentrum Benth. }\end{array}$ & $12 \mathrm{spp}$. & $\begin{array}{l}\text { R. claussenii Benth., R. defformis (Ell.) DC., } \\
\text { R. platyphylla Benth., R. corylifolia Mart., } \\
\text { R. leucophylla Benth., R. lineata Benth., } \\
\text { R. reticulata DC., R. latifolia Nutt. Ex Torr. \& Gray, } \\
\text { R. calycosa Hemsl., R. tomentosa Torr. \& Gray, } \\
\text { R. reniformis (Pursh) DC., R. longiracemosa } \\
\text { M.Martens \& Galeotti. }\end{array}$ \\
\hline Baker (1871) & Rhynchosia Lour. & $\begin{array}{l}\text { Arcyphyllum (Ell.) Torr. \& Gray, Cyanospermum } \\
\text { (Wight \& Arn.) Benth., Copisma E.Mey., } \\
\text { Dolichoides Baker. }\end{array}$ & 2 spp. & $\begin{array}{l}\text { R. debilis Hook. (= R. densiflora subsp. debilis } \\
\text { (G.Don) Verdc.), R. densiflora (Roth) DC. }\end{array}$ \\
\hline Baker (1923) & Rhynchosia Lour. & $\begin{array}{l}\text { Arcyphyllum (Ell.) Torr. \& Gray, } \\
\text { Chrysoscias E.Mey., Cyanospermum (Wight \& Arn.) } \\
\text { Benth., Polytropia Presl., Rhynchosia Lour. }\end{array}$ & $2 \mathrm{spp}$. & $\begin{array}{l}\text { R. connata Baker f., R. densiflora (Roth) DC. } \\
\text { (= Rhynchosia densiflora subsp. chrysadenia } \\
\text { (Taub.) Verdc.) }\end{array}$ \\
\hline
\end{tabular}


TABLE 2: Distinguishing features between subspecies of Rhynchosia densiflora.

\begin{tabular}{|c|c|c|c|c|}
\hline Character & R. densiflora subsp. densiflora & R. densiflora subsp. debilis & R. densiflora subsp. chrysadenia & R. densiflora subsp. stuhlmannii \\
\hline Leaflet apex & Acute or subacute & Acute or acuminate & Obtuse or slightly acuminate & Obtuse \\
\hline Leaflet gland, colour & Yellow to orange-red & Black & Yellow to orange-red & Black \\
\hline Raceme length & $1.0 \mathrm{~cm}-4.5 \mathrm{~cm}$ & $1.0 \mathrm{~cm}-2.0 \mathrm{~cm}$ & $3.0 \mathrm{~cm}-16.5 \mathrm{~cm}$ & $1.5 \mathrm{~cm}-4.5 \mathrm{~cm}$ \\
\hline Bract length & $5-9 \times 1 \mathrm{~mm}-2 \mathrm{~mm}$ & $4-5 \times 1.0 \mathrm{~mm}-1.5 \mathrm{~mm}$ & $6-16 \times 2.5 \mathrm{~mm}-5.0 \mathrm{~mm}$ & $4-11 \times 1 \mathrm{~mm}-7 \mathrm{~mm}$ \\
\hline Calyx lobe, length & $7 \mathrm{~mm}-13 \mathrm{~mm}$ & $5.0 \mathrm{~mm}-7.5 \mathrm{~mm}$ & $10 \mathrm{~mm}-17 \mathrm{~mm}$ & $7 \mathrm{~mm}-12 \mathrm{~mm}$ \\
\hline
\end{tabular}

Source: Based on Verdcourt, B., 1971, 'Studies in the Leguminosae-Papilionoideae for the Flora of Tropical East Africa II', Kew Bulletin 25, 70-112. https://doi.org/10.2307/4103150 key to the subspecies

South Africa. Verdcourt (1971) differentiated these taxa based predominantly on the length of the inflorescence. The differences are summarised in Table 2. Based on Verdcourt's (1971) circumscription, R. connata falls within the $R$. densiflora complex in that it has a similar growth form (climbing, procumbent perennial herbs about $0.8 \mathrm{~m}$ long), obtuse leaflets and yellow glands on the leaflets. According to Baker (1923), R. connata differs from $R$. densiflora mainly in the shape of the terminal leaflet (rhombic-ovate in the former and broadly ovate in the latter) as well as stipule shape (ovate in $R$. connata vs. lanceolate in $R$. densiflora), and the length of the terminal leaflet petiolule $(8 \mathrm{~mm}-$ $10 \mathrm{~mm}$ in $R$. connata vs. $10 \mathrm{~mm}-18 \mathrm{~mm}$ in $R$. densiflora). Examination of numerous herbarium specimens has however revealed that within $R$. densiflora itself, there is a great deal of morphological variation, and therefore none of these characters can be used for diagnostic purposes in separating these two taxa. It is important to mention that descriptions of $R$. connata are based on the type specimen only. Verdcourt (1971) observed that the East African plants of the $R$. densiflora complex exhibit a wide range of morphological variation and as a result concluded that the colour of the glands on the leaves and calyx lobes appears to represent 'a more accurate picture of the evolution of the species' (i.e. R. densiflora). The colour of glands places $R$. connata firmly in this complex, from which it differs only in the size and the extent of connation of the lobes of the uppermost calyx lip. Therefore, this taxon is here included in $R$. densiflora as $R$. densiflora subsp. chrysadenia var. connata (Baker f.) Jaca \& Moteetee.

As part of ongoing studies on the genus Rhynchosia (Boatwright \& Moteetee 2014; Moteetee, Boatwright \& Jaca 2012; Moteetee, Boatwright \& Jaca 2014; Moteetee \& Le Roux 2016), a review of the South African taxa of the $R$. densiflora group is presented, providing complete nomenclature, diagnostic features and distribution maps of the taxa.

\section{Materials and methods}

Plant material was studied from herbarium specimens housed at Natal Herbarium (NH), Bews Herbarium (NU, formerly called Natal University Herbarium) and the National Herbarium, Pretoria (PRE) (Acronyms from Thiers [2011]). Several field excursions were undertaken by the authors and other groups (including the crew) in search of $R$. connata. For the floral dissections, flowers were rehydrated in boiling water and mounted in glycerol and illustrations were drawn using a camera lucida attachment. Images of leaf surfaces and anatomical sections were taken using a Zeiss Stereo microscope,
$6.3 \times$ micro-lens and a Zeiss compound microscope. For anatomical studies, material from herbarium specimens was treated according to a modification of the method of Feder and O'Brien (1968). Thin sections were made using a 2045 Multicut Rotary Microtome. Staining was performed using the periodic acid Schiff-toluidine blue staining method. For scanning electron microscopy (SEM) studies of the leaf and calyx surface appendages, material was sputter-coated with gold and examined using a Phenon Pro SEM.

\section{Results \\ Vegetative morphology}

Taxa of the $R$. densiflora group are characterised by mostly twining, erect or prostrate stems and unifoliolate or trifoliolate leaves, although the South African taxa are exclusively trifoliolate. Plants are vigorous climbing, procumbent or ascending perennial herbs, $0.2 \mathrm{~m}-8.0 \mathrm{~m}$ long. Stems are slender, firm-herbaceous, shortly pubescent to densely grey-pilose and glandular (Figure 1). Leaflet shape ranges from elliptic-ovate, rhomboidal to rhomboidal-ovate or almost round. In $R$. densiflora subsp. chrysadenia and $R$. densiflora subsp. connata, the terminal leaflets are ellipticovate, rhombic-ovate, obtuse to subacute or apiculate, whereas the lateral leaflets are acute or apiculate, oblique, rounded to cuneate at the base. The vestiture is finely scaly pubescent on the midrib and other veins to softly pubescent on both sides of the leaflets, and both surfaces of the leaflets are covered with small orange glands although these are more abundant on the upper surface (Figure 2). SEM micrographs and cross sections of the leaf revealed that these glands are bulky-capitate and are located in depressions of the epidermis (Figure 3). Cross sections of the petiole of $R$. densiflora subsp. chrysadenia revealed that the petiole has a somewhat irregular shape with orbicular epidermal cells and a ring of five isolated bundles (Figure 3b).

\section{Reproductive morphology}

The $R$. densiflora group is characterised by flowers mostly in dense sessile, subsessile or pedunculate racemes. The inflorescences are axillary racemes and comprise many flowers, a character that is considered ancestral in Rhynchosia (Grear 1978). The inflorescence varies from $10 \mathrm{~mm}$ to $130 \mathrm{~mm}$ long or more (Grear 1978). The extent of fusion of the upper calyx lobes is a useful diagnostic character between typical $R$. densiflora subsp. chrysadenia and $R$. densiflora subsp. chrysadenia var. connata; in the former, the upper calyx lobes are connate up to halfway, whereas in the latter the upper calyx lobes are connate to more than halfway. The standard 


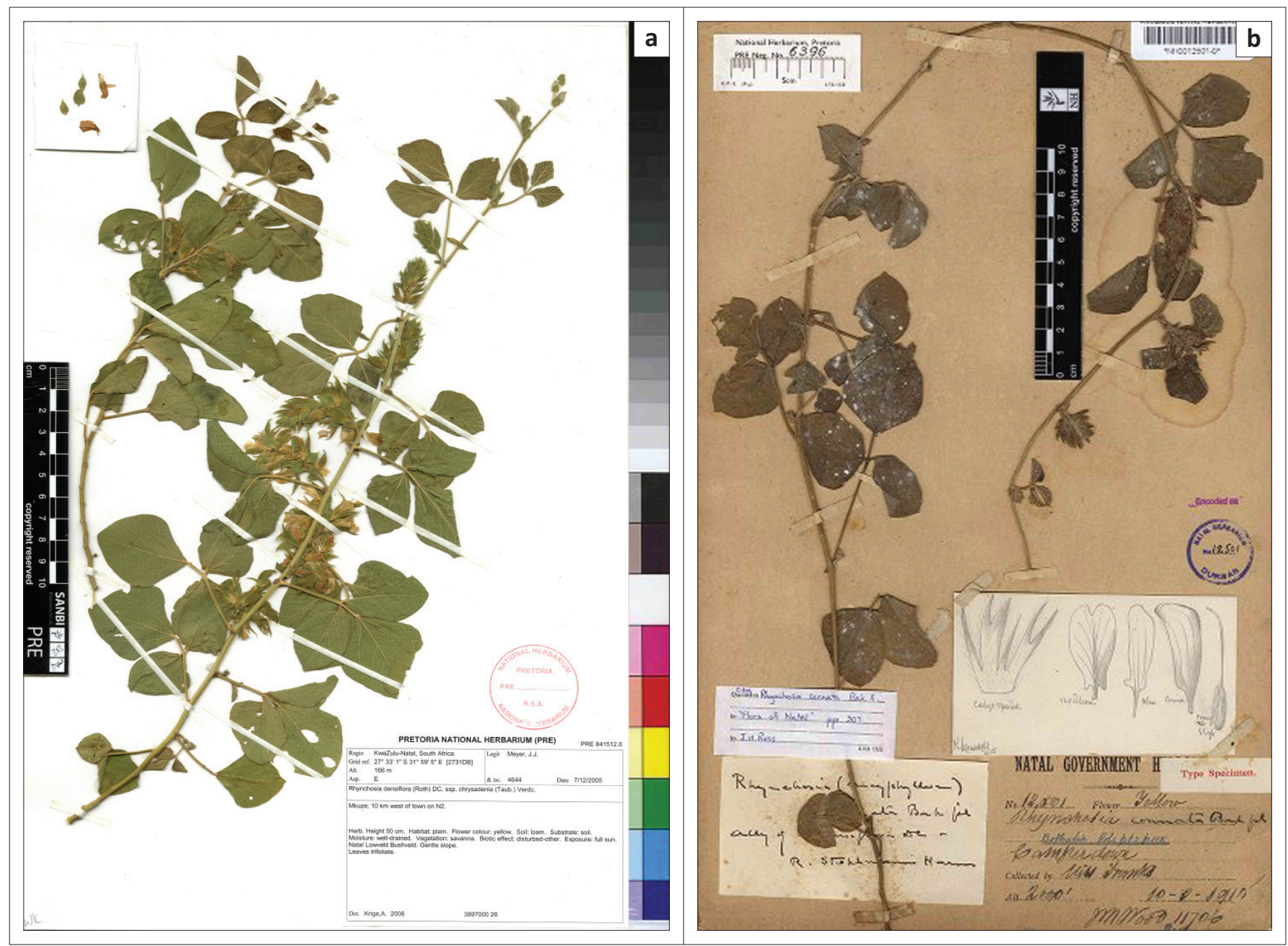

FIGURE 1: Morphology and growth habit of the varieties of Rhynchosia densiflora. (a) R. densiflora subsp. chrysadenia var. chrysadenia [Meyer 4644 (PRE)]; (b) R. densiflora subsp. chrysadenia var. connata [Franks $12501(\mathrm{NH})$ ].

petal is glabrous and eglandular. The lamina of the wing petal is generally oblong, without surface sculpturing, and is glabrous. There seems to be some variation in keel petal length and width in $R$. densiflora subsp. chrysadenia, and in var. connata the keel is slightly narrower $(8 \mathrm{~mm} \times 4 \mathrm{~mm})$ than in var. chrysadenia $(10 \mathrm{~mm}-12 \mathrm{~mm} \times 3 \mathrm{~mm}-4 \mathrm{~mm})$.

\section{Taxonomic treatment}

Rhynchosia densiflora (Roth) DC. in Prodr. 2: 386 (1825); Gen. Hist. 4: 345 (1832); Baker in F.T.A. 2: 222 (1871); Meikle in F.W.T.A., ed. 2(1): 555 (1958); Verdcourt in Kew Bull. 25: 72 (1971); F.T.E.A., Leguminosae, Pap. 4: 723 (1971); Lock, Leg. Afr. Check-list: 428 (1989); Verdcourt in FZ 3(5): 174 (2001). Glycine densiflora Roth in Nov. Pl. Sp.: 348 (1821). Type: India, 01 Jan. 1814, Heyne s.n. (L, lecto.! designated here; K isolecto.!). [Note: The specimen in $\mathrm{L}$ is chosen as a lectotype for $R$. densiflora because Roth's publication of the 'Novae plantarum species praesertim Indiae orientalis' was based on the botanical collection donated to him by Benjamin Heyne as indicated in his foreword.]

Climbing, procumbent or ascending perennial herb $0.3 \mathrm{~m}-$ $3.0 \mathrm{~m}$ long; stems mostly slender, twining, shortly pubescent to densely grey-pilose and glandular with longitudinal grooves. Stipules: ovate-lanceolate, acute, (4-)5-6(-8) $\mathrm{mm} \times 2-4 \mathrm{~mm}$, densely pubescent to tomentose and glandular-punctate. Leaves: papyraceous; leaflets elliptic, ovate, elliptic-ovate, rhombic or suborbicular, $15 \mathrm{~m}-80 \mathrm{~m} \times 10 \mathrm{~m}-72 \mathrm{~m}$, obtuse, acute or markedly acuminate at the apex, lateral leaflets rounded to oblique at base, finely scaly pubescent on veins to softly pubescent on both surfaces, densely covered with small orange or black glands beneath; petiole $20 \mathrm{~mm}-70 \mathrm{~mm}$ long, grey-pilose and glandular; petiolules $6 \mathrm{~mm}-11(-13) \mathrm{mm}$. Inflorescences: axillary, sometimes branched; peduncle (0.5-) $4.0 \mathrm{~mm}-20.0(-40.0) \mathrm{mm}$ long, rhachis $20 \mathrm{~mm}-130 \mathrm{~mm}$ long. Bracts: lanceolate, acuminate, (4.0-)8.0-16.0 mm × 1.0-7.5 mm, pilose or pubescent. Calyx: pubescent or pilose and glandularpunctate; tube $1.5 \mathrm{~mm}-2.0 \mathrm{~mm}$ long; lobes linear or linearlanceolate, acute, lower lip broader than upper lip, lobes of upper lip connate less than halfway to almost entirely, lobes of lower lip unequal. Corolla: slightly longer than calyx; standard yellow with purple venation, elliptic to oblong, $9 \mathrm{~mm}-15 \mathrm{~mm} \times 4 \mathrm{~mm}-9 \mathrm{~mm}$, glabrous, auriculate, slightly emarginate apically; wings oblong-lanceolate, $6.0 \mathrm{~mm}-$ $10.0 \mathrm{~mm} \times 1.5 \mathrm{~mm}-3.0 \mathrm{~mm}$, distinctly shorter than standard petal, glabrous; keels oblong to obovate, $8 \mathrm{~mm}-12 \mathrm{~mm} \times$ $3 \mathrm{~mm}-4 \mathrm{~mm}$, larger than wing. Stamens: diadelphous, anthers 


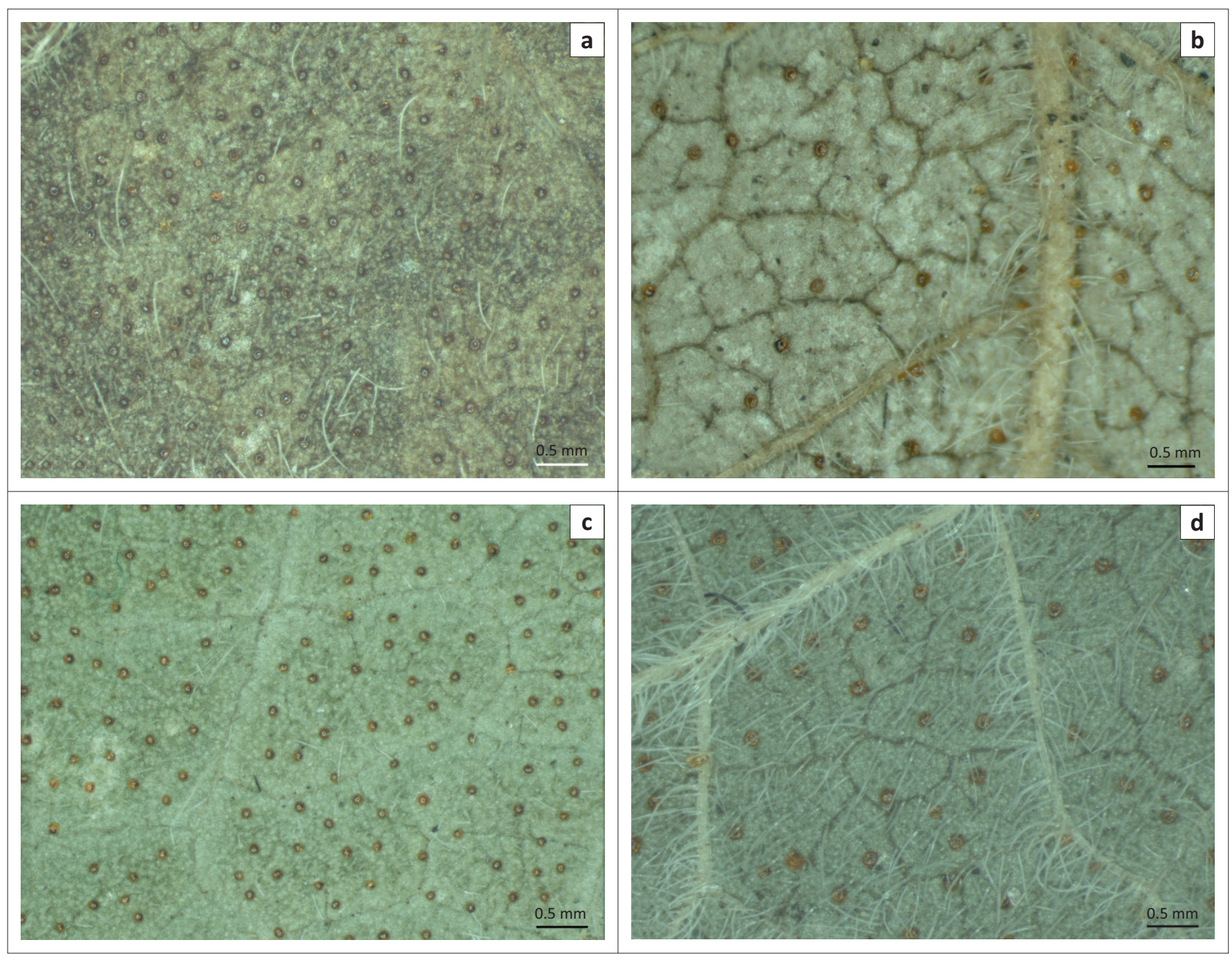

FIGURE 2: Leaflets showing the indumentum on the adaxial and abaxial surfaces. (a) Rhynchosia densiflora subsp. chrysadenia var. connata adaxial surface; (b) R. densiflora subsp. chrysadenia var. connata abaxial surface [Franks 12501 (NH)]; (c) R. densiflora subsp. chrysadenia var. chrysadenia adaxial surface; (d) R. densiflora subsp. chrysadenia var. chrysadenia abaxial surface [Bester 5484 (PRE)].

uniform, dorsifixed, longitudinally dehiscent. Ovary: narrowly oblong, subsessile, densely silky-villous, glandular-punctate, 2-ovuled. Style: shortly pubescent and glandular. Stigma: exserted beyond stamens. Fruit: elliptic-oblong or oblong, (9-)12-17 mm $\times 5 \mathrm{~mm}-6 \mathrm{~mm}$, densely covered with short grey-pubescence or sparser long hairs and orange-red gland dots, longitudinally dehiscent. Seeds: depressed-globular, $4 \mathrm{~mm}-5 \mathrm{~mm} \times 3.0 \mathrm{~mm}-3.5 \mathrm{~mm}$, brown with black mottling or almost entirely black, oblong-reniform.

\section{Key to South African taxa of $\boldsymbol{R}$. densiflora}

1a Inflorescence rachis (19-)26 mm - 105(-130) mm long; upper calyx lobes connate to halfway

R. densiflora subsp. chrysadenia var. chrysadenia

1b Inflorescence rachis $14 \mathrm{~mm}-33 \mathrm{~mm}$ long; upper calyx lobes connate more than halfway

R. densiflora subsp. chrysadenia var. connata

Rhynchosia densiflora subsp. chrysadenia (Taub.) Verdc. in Kew Bull. 25: 73 (1971); Verdc. in F.T.E.A., Leguminosae, Pap.: 726
(1971); Drummond in Kirkia 8: 226 (1972); Lock, Leg. Afr. Checklist: 428 (1989). Rhynchosia chrysadenia Taub. in Pflanzenw. OstAfr. C: 222 (1895); Bak. f., Legum. Trop. Afr.: 470 (1929).

Type: Tanzania, Pare District, Maasai Steppe?, without date, Fischer 88 (B $\dagger$, HBG, lecto.! designated here). [The specimen in $\mathrm{HBG}$ is chosen as a lectotype for $R$. densiflora subsp. chrysadenia as it has flowers and a label with Taubert's handwriting. The specimen was also cited by Verdcourt (1971).]

Rhynchosia fischeri Harms in Bot. Jahrb. Syst. 26: 305 (1899); Bak. f., Legum. Trop. Afr.: 470 (1929). Type: East Africa, without precise locality, without date, Fischer 76 (B†, HBG, lecto.! designated here). [The specimen in HBG is chosen as a lectotype for $R$. fischeri as it is the only available specimen.]

Rhynchosia schweinfurthii Harms in Bot. Jahrb. Syst. 26: 307 (1899); Bak. f., Legum. Trop. Afr.: 470 (1929). Type: Sudan, Seriba Ghattas, 10 Sept. 1869, Schweinfurth 2335 (B†, K, lecto.! designated here; $\mathrm{S}, \mathrm{P}$, isolecto.!). [The specimen in $\mathrm{K}$ is chosen 


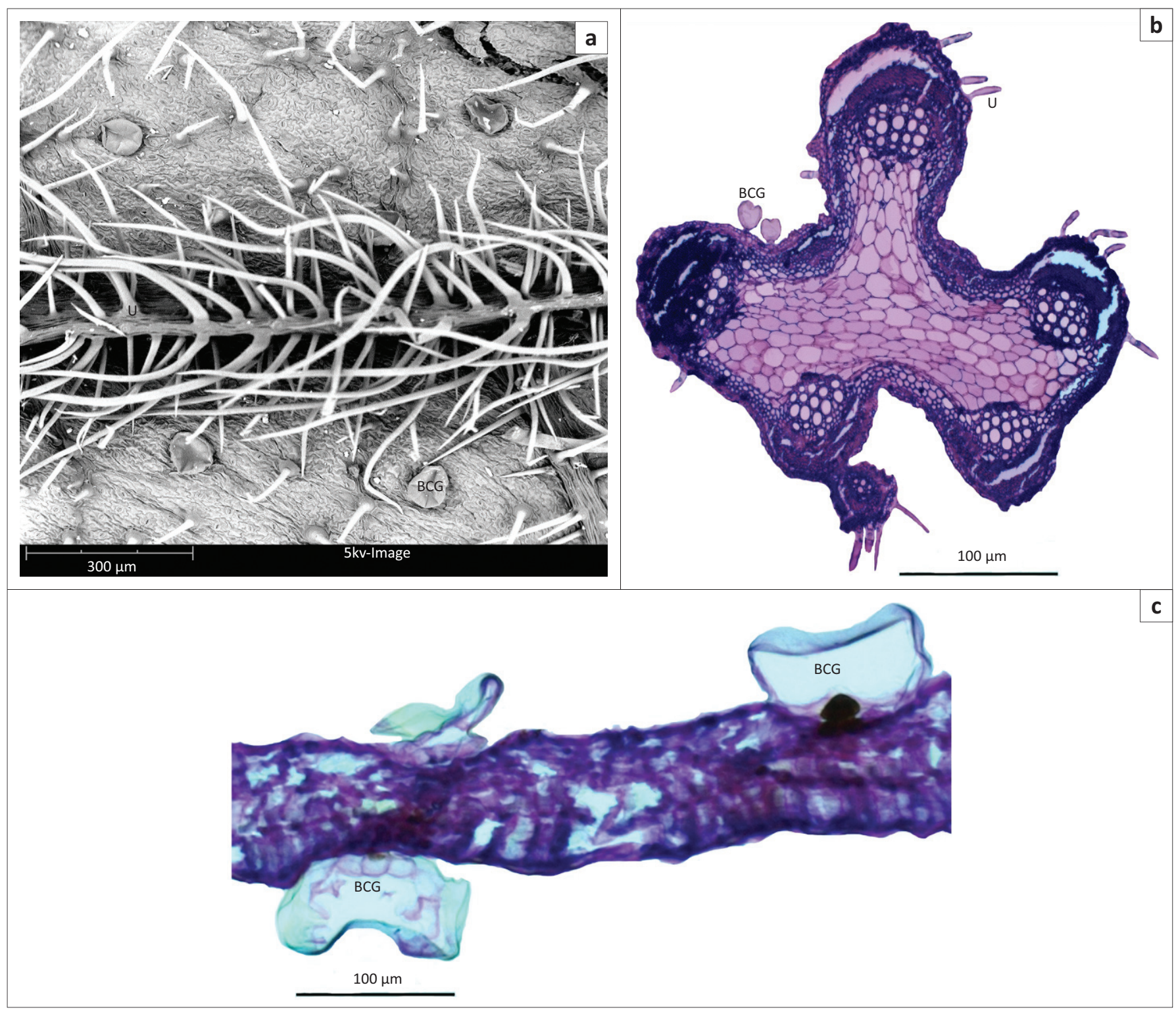

FIGURE 3: Scanning electron microscopy micrographs (a), cross section of petiole (b) and leaf (c) in R. densiflora subsp. chrysadenia, showing the arrangement of tissues and the external morphology of the trichomes (U, uniseriate hairs; BCG, bulky-capitate glands). Vouchers: (a) from Galpin M585 (PRE); (b and c) from Hardy 2223 (PRE).

as lectotype for R. schweinfurthii as it is of good quality and the illustration of flower dissection attached to the sheet shows the characteristic features of the flowers.]

Rhynchosia glomerulans Fiori in Nuov. Giorn. Ital. nuov. ser. 19: 455, t. (1912-13). Type: Ethiopia, Eritrea, Hamacen from Filfil to Mogho, 01 Apr. 1909, Fiori 1140 (FT, holo.!).

Leaflets: rhombic to elliptic-ovate, terminal leaflets apiculate or obtuse, (30-)40-60(-75) $\mathrm{mm} \times 28-55(-60) \mathrm{mm}$, finely scaly pubescent on veins, softly pubescent on both surfaces, densely covered with yellow to orange-red gland dots; petioles (40-) $42 \mathrm{~mm}-65(-70) \mathrm{mm}$ long; petiolules of terminal leaflets $6 \mathrm{~mm}-11(-13) \mathrm{mm}$ long. Inflorescence: rachis (19-)26 mm - 105(-130) $\mathrm{mm}$ long, peduncles $5 \mathrm{~mm} \mathrm{-} \mathrm{20(-40)} \mathrm{mm}$ long. Bracts: $8 \mathrm{~mm}-15 \mathrm{~mm} \times 3 \mathrm{~mm}-5 \mathrm{~mm}$. Calyx: upper lip $9 \mathrm{~mm}-10 \mathrm{~mm}$ long, lower lip $11 \mathrm{~mm}-16 \mathrm{~mm}$ long, lobes of upper lip connate to halfway. Standard: elliptic to oblong, $12 \mathrm{~mm}-15 \mathrm{~mm} \times 4 \mathrm{~mm}-9 \mathrm{~mm}$; claw: $2 \mathrm{~mm}-3 \mathrm{~mm}$ long; wings: $8 \mathrm{~mm}-10 \mathrm{~mm} \times 2 \mathrm{~mm}-3 \mathrm{~mm}$, claw: $2.5 \mathrm{~mm}-3.0 \mathrm{~mm}$ long; keel: $10-12 \mathrm{~mm} \times 3 \mathrm{~mm}-4 \mathrm{~mm}$, claw $3 \mathrm{~mm}-4 \mathrm{~mm}$ long (Figure 4). Gynoecium: $14 \mathrm{~mm}-17 \mathrm{~mm}$ long; androecium: $11 \mathrm{~mm}-13 \mathrm{~mm}$ long. Fruits: $12 \mathrm{~mm}-17 \mathrm{~mm} \times 5 \mathrm{~mm}-6 \mathrm{~mm}$. Flowering time: November-April.

\section{Diagnostic characters:}

Rhynchosia densiflora subsp. chrysadenia var. chrysadenia is distinguished from var. connate by the longer inflorescence, (19-)26 mm-105(-130) mm long with peduncles $5 \mathrm{~mm}-15 \mathrm{~mm}$ long versus $14 \mathrm{~mm}-33 \mathrm{~mm}$ long with very short peduncles $3 \mathrm{~mm}-7 \mathrm{~mm}$ long. The lobes of the upper calyx lip are connate up to halfway, whereas in var. connata they are connate more than halfway, sometimes connate almost to the apex.

\section{Distribution and ecology:}

Rhynchosia densiflora subsp. chrysadenia var. chrysadenia is widespread from northeast and northwest South Africa, 


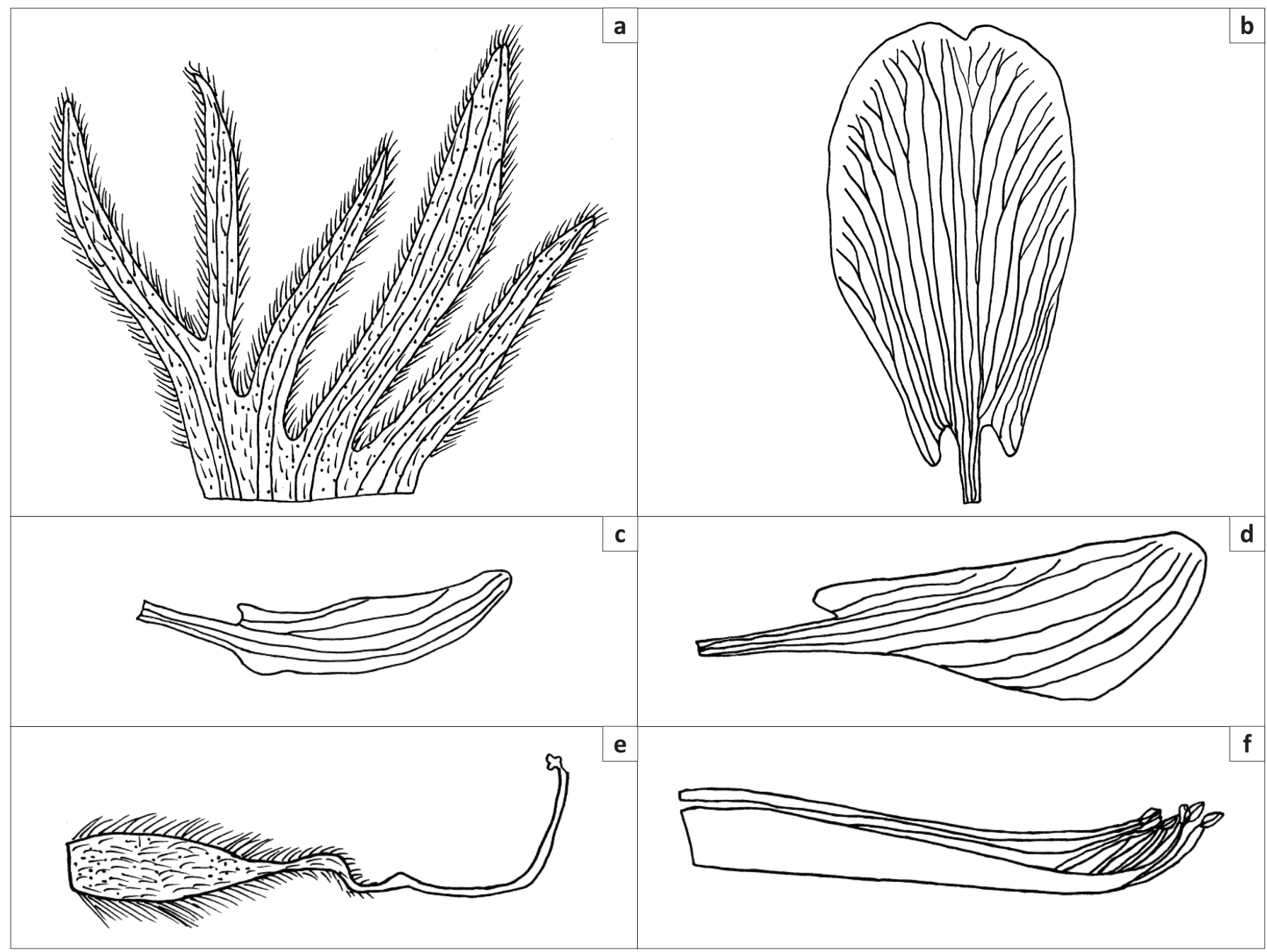

FIGURE 4: Floral morphology of Rhynchosia densiflora subsp. chrysadenia var. chrysadenia [Crawford 458 (PRE)]: (a) calyx opened with upper lobes to the left; (b) standard petal; (c) wing petal; (d) keel petal; (e) gynoecium; (f) androecium. Scale bar: $6 \mathrm{~mm}$.

Botswana and Namibia northwards into Tropical East Africa (Kenya, Rwanda, Tanzania, Uganda, Ethiopia, Democratic Republic of Congo) to inland regions (Verdcourt 2001). In South Africa R. densiflora subsp. chrysadenia occurs from the northern and north-eastern regions in KwaZulu-Natal northwards to Mpumalanga, North West, Gauteng and Limpopo provinces (Figure 5). This taxon grows in open and short grasslands on mountain slopes, rocky outcrops, open woodlands, forest margins, savannah habitats and thickets of riverine vegetation.

\section{Additional specimens examined}

SOUTH AFRICA. LIMPOPO. - 2329 (Pietersburg): HaKutama (Maebane) (-BA), 03 Mar. 1981, Netshiungani 1390 (PRE); $5 \mathrm{~km}$ from great north road towards Elim (-BD), 08 Mar. 1976, Crawford 458 (PRE). 2331 (Kruger National Park): Tendi Flats; about 15 km from river (-CA), 16 Feb. 1954, Van der Schijff 3526 (PRE); Makulane (-CD), Aug. 1919, Junod TRV 21522 (PRE). 2427 (Thabazimbi): Rooiberg (-CB), 09 Feb. 1958, Repton 4849 (PRE). 2428 (Nylstroom): Hoedspruit (-AC), Shlaralumi Road, $4 \mathrm{~km}$ from junction to White River, 16 Oct. 1981, Zambatis 1226 (PRE); Mogalakwena River (-BB), 21 Jan. 1894, Schlechter 4277 (PRE); Manyeleti Game Reserve,
Hermitage (-CB), 23 Mar. 1977, Bredenkamp 1812 (PRE); Warmbaths to Woomba Past. Res. (-CD) 12 Feb. 1948, Sidey 1476 (PRE); Apr. 1980, Collett 496 (PRE); Warmbaths, on road to Pretoria, 11 Mar. 1978, Germishuizen 803 (PRE); Naboomspruit, Mosdene at Vogelstruispan (-DA) 03 Mar. 1919, Galpin M94 (PRE); 19 Mar. 1923, Galpin M585, (PRE); Settlers, outskirts of village (-DC), 05 Nov. 1972, Clarke 407 (PRE). 2429 (Zebediela): (-AA), Apr. 1931, St John 24 (PRE); no precise locality, Nov. 1908, Leendertz 1212 (PRE).

NORTH WEST. - 2526 (Zeerust): Shainsdrift, near camp (-AD), 24 Apr. 1927, Liebenberg S73 (PRE). 2527 (Rustenburg): Doornhoek Farm, south side of Pilanesberg (-AA), 20 Mar. 1946, Codd 1103 (PRE); Saulspoort, 12 Nov. 1977, Germishuizen \& Retief 515 (PRE); Pilanesberg, Doornhoek Farm, South-Border of Pilansberg (-AC), 20 Mar. 1946, Story 1006 (PRE); Kopje near town (-CA), 06 Feb. 1929, Hutchinson 2939 (PRE); Brits, Hartebeestpoort Farm near southeast summit of Rooiberg series Kopjie (-DB), 23 Feb. 1939, Mogg 16680 (PRE); near Cashel Hotel, 14 Mar. 1946, Acocks 12555 (PRE).

GAUTENG. - 2528 (Pretoria): Lower Springbok Flat, Bosplaas $10 \mathrm{~km}$ south of Pienaarsriver (-AD), 26 Apr. 1939, Mogg 16818 


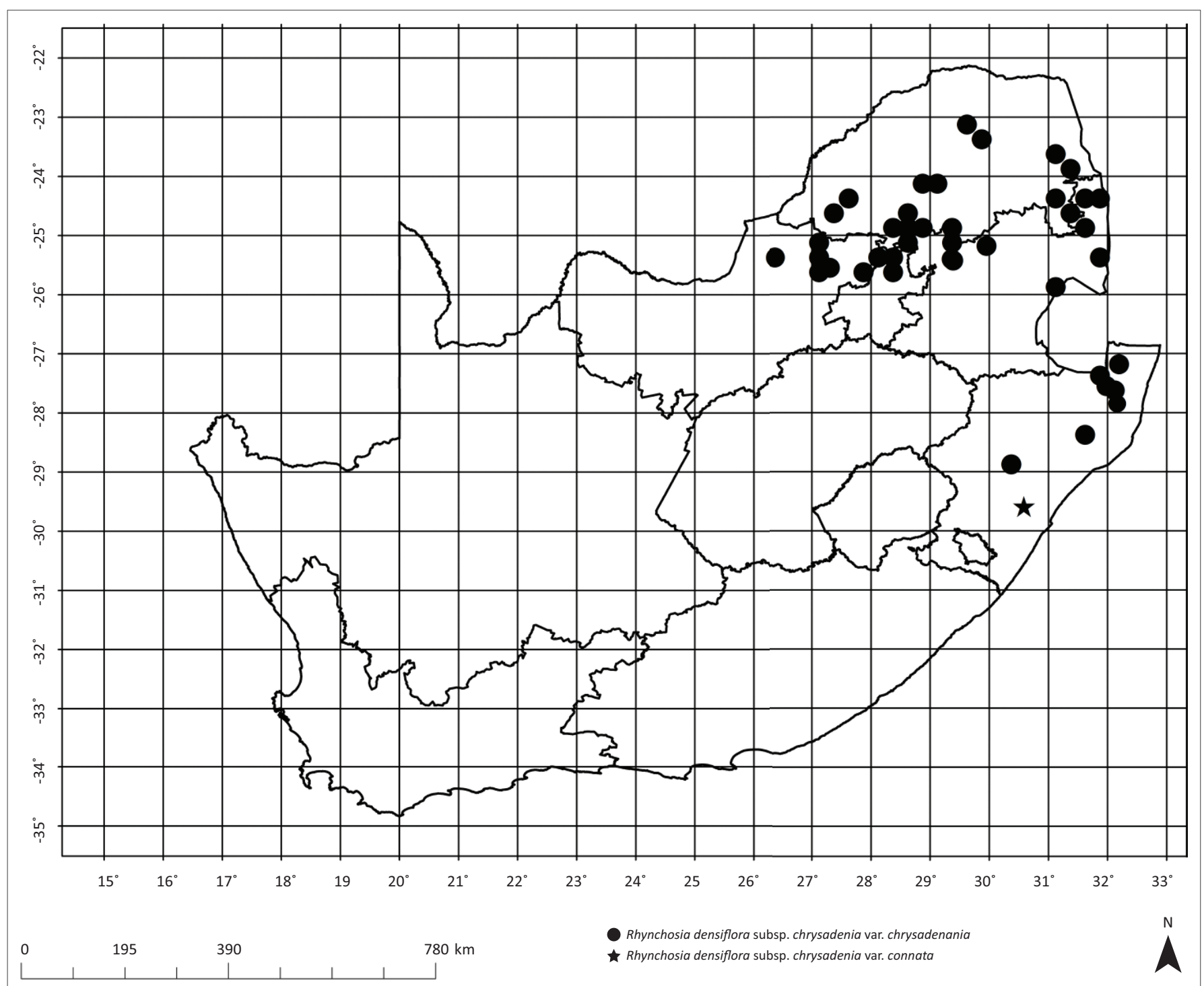

FIGURE 5: Distributions of Rhynchosia densiflora subsp. chrysadenia var. chrysadenia and Rhynchosia densiflora subsp. chrysadenia var. connata in South Africa.

(PRE); Rust De Winter (-BA), 20 Feb. 1936, Pole Evans 3911 (PRE); Rooiplaat, Pienaars River (-CB) 22 Mar. 1906, Leendertz 783 (PRE).

MPUMALANGA. - 2428 (Nylstroom): Debeersput (-DD) $3 \mathrm{~km}$ from Marapyane on road to Groblersdal, 03 Mar. 1986, Germishuizen 3717 (PRE). 2429 (Zebediela): H 71 Hoewe (-CD), 30 Dec. 1965, Grobbelaar 469 (PRE). 2431 (Acornhoek): Satara (-BC), Mar. 1975, Gertenbach 5039 (PRE); (-BD), 24 Feb. 1953, Van der Schijff 2257 (PRE); Kumane Dam (-DC) 10 miles north of dam, 09 Dec. 1953, Van der Schijff 3368 (PRE). 2529 (Witbank): from Groblersdal on Stoffberg road (-AB), 03 Mar. 1966, Hardy 2223 (PRE); Loskop Dam Nature Reserve (-AD), 23 Jan. 2002, Potgieter FP00291 (PRE); Mapochs Grounds, ca. 8 km northeast from Roossenekal (-BB), 19 Jan. 2005, Bester 5484 (PRE). 2531 (Komatipoort): between Krokodilbrug and Gomondwene (-BD), 11 Nov. 1954, Van der Schijff 4028 (PRE). 2531 (Barberton): Barberton area (-CC), Feb. 1915, Thorncroft PRE11274 (PRE), Nov. 1914, Thorncroft 888 (NH). 2731 (Louwsburg): Pongolapoort (-BD), 10 Nov. 1987, Kluge 2733 (PRE).
KWAZULU-NATAL. - 2732 (Ubombo): Ingwavuma (-AA) about 400 m north of Ndumu Store, 02 Jun. 1969, Pooley 549 (NU) Mkuze Game Reserve (-CA), 1977, Goodman 1100 (NH); 29 Mar. 1977, Goodman 970 (NU); 18 Jan. 1965, Strey 5648 (NU, PRE); Mkuze, $10 \mathrm{~km}$ west of town on N2, 07 Dec. 2005, Meyer 4644 (PRE). 2830 (Dundee): $9 \mathrm{~km}$ from Muden on road to Colenso (-CD), 23 Jan. 1985, Pienaar 419 (PRE, NH). 2831 (Nkandla): Umfolozi Game Reserve, Cengeni gate (-BC), 11 Nov. 1984, Venter 55 (NH).

Rhynchosia densiflora subsp. chrysadenia var. connata (Baker f.) Jaca \& Moteetee, stat. nov. R. connata Baker f. in Bothalia 1: 117 (1923). Type: South Africa, KwaZulu-Natal Province, Camperdown (-DA), 10 Feb. 1910, Franks 12501/ Wood 11706 (NH, holo!). [Baker (1923) listed Franks 1250 for R. connata and Wood 11706 for R. densiflora. Upon examining the type specimen it became clear that both Miss Franks 12501 and Wood 11706 in NH, appear in Wood's handwriting on a specimen determined as $R$. connata by Baker. It is evidently an error that Baker cited Franks 1250 instead of Franks 12501.] 


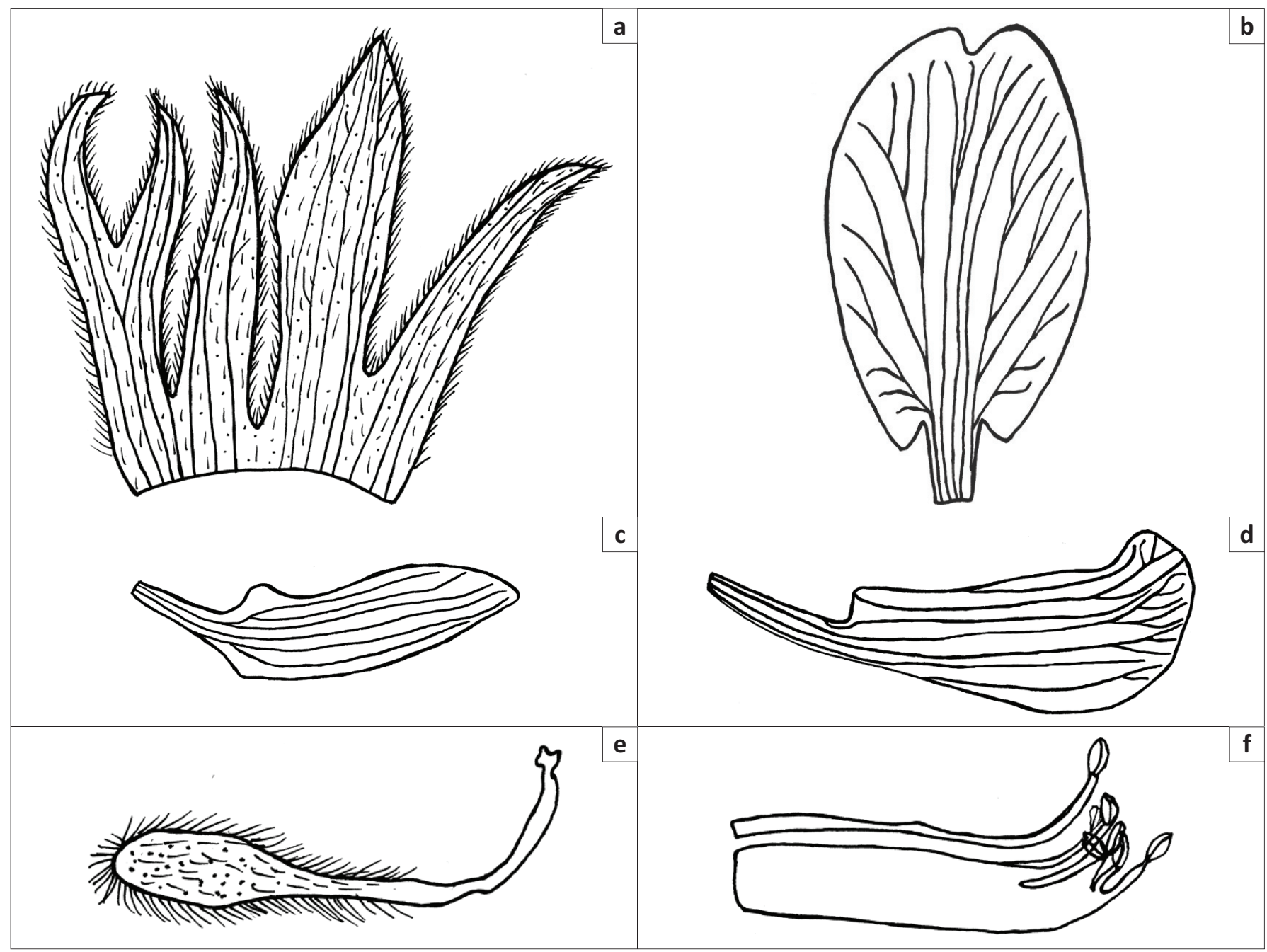

FIGURE 6: Floral morphology of Rhynchosia densiflora subsp. chrysadenia var. connata [Franks 12501 (NH)]: (a) calyx opened with upper lobes to the left; (b) standard petal; (c) wing petal; (d) keel petal; (e) gynoecium; (f) androecium. Scale bar: $6 \mathrm{~mm}$.

Leaflets: rhombic to elliptic-ovate, terminal leaflets obtuse or apiculate, $40 \mathrm{~mm}-46 \mathrm{~mm} \times(18-) 20-40 \mathrm{~mm}$, finely scaly pubescent on veins, softly pubescent on both surfaces, densely covered with yellow to orange-red gland dots; petioles $40 \mathrm{~mm}-55 \mathrm{~mm}$ long; petiolules of terminal leaflets (6-) $8 \mathrm{~mm}-11 \mathrm{~mm}$ long. Inflorescence: rachis $14 \mathrm{~mm}-33 \mathrm{~mm}$ long, peduncles $3 \mathrm{~mm}-7 \mathrm{~mm}$ long. Bracts: $8 \mathrm{~mm}-16 \mathrm{~mm} \times$ $3 \mathrm{~mm}-4 \mathrm{~mm}$. Calyx: upper lip $9 \mathrm{~mm}$ long, lower lip $10 \mathrm{~mm}$ long, lobes of upper lip connate more than halfway, sometimes almost to apex. Standard: oblong, $9 \mathrm{~mm} \times 4 \mathrm{~mm}$; claw: $2 \mathrm{~mm}-3 \mathrm{~mm}$ long; wings: $6.0 \mathrm{~mm} \times 1.5 \mathrm{~mm}$, claw: $3 \mathrm{~mm}$ long; keel: $8 \mathrm{~mm} \times 4 \mathrm{~mm}$, claw: $4 \mathrm{~mm}$ long, obtuse (Figure 6). Gynoecium: $13 \mathrm{~mm}-15 \mathrm{~mm}$ long; androecium: $11 \mathrm{~mm}-13 \mathrm{~mm}$ long. Fruits: and seeds not seen. Flowering time: the only existing specimen of this taxon was collected in March.

\section{Diagnostic characters:}

Rhynchosia densiflora subsp. chrysadenia var. connata is similar to $R$. densiflora subsp. chrysadenia var. chrysadenia in growth form, from which it can be distinguished by its generally much shorter $14 \mathrm{~mm}-33 \mathrm{~mm}$ long inflorescence, (opposed to 26-105[-130] $\mathrm{mm}$ ) and peduncles that are $3 \mathrm{~mm}-7 \mathrm{~mm}$ long (vs. $5 \mathrm{~mm}-15 \mathrm{~mm}$ long). The lobes of the upper calyx lip are connate to more than half the length or sometimes almost connate to the apex, whereas in R. densiflora subsp. chrysadenia they are connate to the middle or below the middle. Baker (1923) mentioned that this species is an ally of R. stuhlmannii Harms (now R. densiflora subsp. stuhlmannii [Harms] Verdc.), which occurs mainly in tropical Africa.

\section{Distribution and ecology:}

Rhynchosia densiflora subsp. chrysadenia var. connata is known only from the type locality in Camperdown, KwaZulu-Natal, South Africa (Figure 5), in grasslands at altitudes of about $770 \mathrm{~m}$ above the sea level (a.s.l). Several attempts were made to locate live specimens in the area, all of which were futile.

\section{Acknowledgements}

The curators of $\mathrm{NH}$ and PRE are gratefully acknowledged for their assistance with herbarium material. The University of Johannesburg and the National Research Foundation Thuthuka programme are thanked for their financial support. 


\section{Competing interests}

The authors declare that they have no financial or personal relationships that may have inappropriately influenced them in writing this article.

\section{Authors' contributions}

T.P.J. and A.N.M. contributed equally to this article in conceptualisation and execution of the study. T.P.J. compiled the initial manuscript, while A.N.M. was involved in the editing process.

\section{References}

Baker, E.G., 1923, 'Revision of South African species of Rhynchosia', Bothalia 1 113-138.

Baker, J.G., 1871, 'Leguminosae', in D. Oliver (ed.), Flora of Tropical Africa, vol. 2, pp. 216-223, Reeve \& Co, London.

Bentham, G., 1859, 'Leguminosae I. Papilionaceae', in C.F.P. Martius (ed.), Flora Brasiliensis, vol. 15, no. 1, pp. 200-206, Apud Frid, Fleischer, Leipzig.

Bentham, G., 1865, 'Leguminosae', in G. Bentham \& J.D. Hooker (eds.), Genera Plantarum, vol. 1, no. 433-600, Lovell Reeve, London.

Boatwright, J.S. \& Moteetee, A.N., 2014, 'Rhynchosia bolusii (Phaseoleae, Fabaceae), a new species from the Western Cape Province of South Africa', Phytotaxa 161(2), 169-172. https://doi.org/10.11646/phytotaxa.161.2.9

Elliott, S., 1818, 'Observations on the genus Glycine and some of its kindred genera' Journal of the Academy of Natural Sciences of Philadelphia 1, 371-372, D. Heart printers, Philadelphia, PA.

Elliott, S., 1824, A sketch of the Botany of South-Carolina and Georgia 2: 234-237, J.R. Schenck Printers, Charleston, SC.

Endlicher, S., 1840, Genera Plantarum Secundum Ordines Naturales Sisposita 2: 1300 Apud Fr. Beck Universitatis, Vindobonae, Vienna.
Feder, N. \& O'Brien, T.P., 1968, 'Plant microtechnique: Some principles and new methods', American Journal of Botany 55(1), 123-142. https://doi.org/10.1002/ j.1537-2197.1968.tb06952.x

Fortunato, R.H., 2000, 'Systematic relationship in Rhynchosia (Cajaninae PhaseoleaePapilionoideae-Fabaceae) from neotropics', in P.S. Herendeen \& A. Bruneau (eds.), Advanced Legume Systematics, vol. 9, pp. 339-353, The Royal Botanical Gardens, Kew.

Germishuizen, G., Meyer, N.L., Steenkamp, Y. \& Keith, M. (eds.), 2006, A checklist of South African plants, Southern African Botanical Diversity Network Report No. 41. SABONET, Pretoria.

Gillett, J.B., Polhill, R.M. \& Verdcourt, B., 1971, Papilionoideae. In Flora of Tropical East Africa, Crown Agents, London.

Grear, J.W., 1978, 'A revision of the New World species of Rhynchosia (LeguminosaeFaboideae)', Memoirs of the New York Botanical Gardens 31, 1-168.

Manyelo, T.S., 2014, 'A phylogenetic study of South African Species of Rhynchosia (Phaseoleae, Fabaceae)', M.Sc. (Botany) [unpublished], University of Johannesburg, viewed from https://ujdigispace.uj.ac.za

Moteetee, A.N., Boatwright, J.S. \& Jaca, T.P., 2012, 'A review of Rhynchosia section Cyanospermum (Phaseoleae, Fabaceae) in South Africa', South African Journal of Botany 81, 124-127. https://doi.org/10.1016/j.sajb.2012.06.007

Moteetee, A.N., Boatwright, J.S. \& Jaca, T.P., 2014, 'A review of Rhynchosia section Polytropia (Phaseoleae, Fabaceae) and a new species from the Western Cape Province, South Africa', Systematic Botany 39(4), 1127-1131. https://doi.org/ $10.1600 / 036364414 \times 683859$

Moteetee, A.N. \& Le Roux, M.M., 2016, 'The Rhynchosia totta complex (Phaseoleae, Fabaceae) in Southern Africa, including the description of a new variety and new species', Bothalia 46(1), a2041. https://doi.org/10.4102/abc.v46i1.2041

Pursh, F., 1814, Systematic arrangement and description of the plants of North America, 1. Printed for White, Cochrance, \& Co., London, pp. 485-486.

Taubert, P., 1894, 'Leguminosae', Die naturlichen pflanzenfamilien 3(3), 373-375.

Thiers, B., 2011, Index herbariorum: A global directory of Public Herbaria and Associated Staff, New York Botanical Garden's Virtual Herbarium, s.l., viewed 12 April 2018, from http://sweetgum.nybg.org/ih/

Torrey, J. \& Gray, A., 1838, 'Rhynchosia', in J. Torrey \& A. Gray (eds.), A flora of North America 1, pp. 283-285, Wiley and Putnan, New York.

Verdcourt, B., 1971, 'Studies in the Leguminosae-Papilionoideae for the Flora of Tropical East Africa II', Kew Bulletin 25, 70-112. https://doi.org/10.2307/4103150

Verdcourt, B., 2001, 'Rhynchosia', in G.V. Pope \& R.M. Polhill (eds.), Flora Zambesiaca, vol. 3, no. 5, pp. 168-210, Royal Botanic Gardens, Kew. 